\title{
What Determines Banks' Profitability? Evidence from Emerging Markets-the Case of the UAE Banking Sector
}

\author{
Anupam Mehta ${ }^{1} \&$ Ganga Bhavani ${ }^{2}$ \\ ${ }^{1}$ Associate Professor at Institute of Management Technology, Dubai, UAE \\ ${ }^{2}$ Assistant Professor at Manipal University, Dubai, UAE \\ Correspondence: Ganga Bhavani, Assistant Professor at Manipal University, Dubai, UAE
}

Received: November 22, 2016

Accepted: January 8, $2017 \quad$ Online Published: January 16, 2017

doi:10.5430/afr.v6n1p77

URL: http://dx.doi.org/10.5430/afr.v6n1p77

\begin{abstract}
The primary objective of this study is to examine the variables that impact the profitability of UAE banks. The current study provides evidence of important bank-specific, macroeconomic, and industry-specific variables that have affected UAE banks' profitability by analyzing balanced panel data for 2006 to 2013. Both Islamic and non-Islamic, domestic commercial banks are considered for the purposes of this study. This paper puts into relief the determinants of the profitability of the domestic commercial banking sector of the UAE. The sample comprises 19 UAE domestic banks. The paper examines internal variables (company-level indicators), which include size, liquidity, and capital adequacy, as well as external variables, which include macroeconomic and industry-specific variables. Panel data regression analysis is used for the analysis. Based on the empirical analysis, the cost efficiency, nontraditional revenue sources, and high asset quality are the most significant bank-specific variables, and bank managers can use them to make future policy decisions. The GDP, a macroeconomic variable, is found to be relevant to the return on assets and return on equity. The model generated in the study can explain a greater than $75 \%$ change in the total variance of various measures of profitability. This paper adds to the body of knowledge by empirically highlighting the most recent and extensive panel data for the entire domestic banking sector of the UAE, undoubtedly one of the most important banking sectors in the Middle East. The paper uses a range of independent variables for the internal, macroeconomic, and industry-specific variables.
\end{abstract}

Keywords: Banking profitability, Industry-specific variables, Islamic and non-Islamic banks, Commercial banks, profit determinants, UAE banking sector

\section{Introduction}

The UAE banking sector is the largest financial system in the Middle East and North Africa region. It is also one of the country's most important non-oil sectors, with an increase in total banking assets from US \$49 billion in 1995 to US $\$ 509$ billion (net) in 2013. The economic importance of the banking sector in the UAE and the lack of relevant research are the primary motivations for analyzing UAE banks' profitability and highlighting the variables that determine their financial health and profitability. The main objective of this study is to provide a framework for investigating the variables or indicators that affect their profitability and making policy recommendations that bank managers could use for future decision-making. The study covers the domestic banking sector in the UAE over an eight-year period (from 2006 to 2013), using panel data to study the behavior of each bank over time and across periods. The paper highlights the empirically significant variables that have had an impact on UAE banks' profitability. It also adds to the existing body of knowledge by empirically putting into relief the most recent extensive panel data for the UAE's entire domestic banking sector, which is undoubtedly one of the most important banking sectors of the Middle East. The paper uses a range of independent variables, which include internal, macroeconomic, and industry-specific variables.

The empirical results show that, by increasing their asset quality and operating efficiency, UAE banks can significantly improve their profitability; moreover, income diversity would lead to an increase in their overall profitability. A high level of liquidity can improve the net interest margin, but, in contrast to many studies, this paper finds it to be a statistically insignificant variable where increasing the return on assets (ROA) and the return on equity (ROE) is concerned. The paper concludes that, by maintaining a high capital adequacy ratio, the banks can increase the overall net interest margin and return on assets. The model generated in the study can explain a greater 
than $75 \%$ change in the total variance of the various measures of profitability. The remainder of this article is organized as follows: The subsequent section is a literature review. Next is a description of the methodology of this paper then an analysis and a discussion of the results. Finally, the article examines the future scope of the study and presents a conclusion.

\section{Literature Review}

A substantial number of empirical studies have been conducted on the banking sectors of developed countries. However, there is a dearth of studies on Middle Eastern banks, and on UAE banks in particular, in the literature. The majority of existing studies focus on evaluating the performance of commercial banks in comparison to that of Islamic banks. Very few deal with the determinants of the banks' profitability. For instance, using data from 14 Islamic banks, Bashir (1999) analyzed the performance of Middle Eastern banks, including Islamic banks, between 1993 and 1998; the study found that banks' profitability performance increased when the leverage was high and the loan to asset ratio was large but decreased when the reserve ratio was high.

Considering the profitability of Islamic banks alone, Hassan and Bashir (2003) evaluated a range of variables such as capital, overhead, gross domestic product, and conventional interest rates. Loan ratios, reserves, taxes, and size were adversely related to profitability, whereas increases in capital led to positive relationships with profitability. By contrast, loan ratios and bank size were negatively related to profitability. Interestingly, the findings showed that the overhead was positively and significantly related to the non-interest margin but had no significant impact on the return on assets (ROA) and return on equity (ROE). The growth rate of the GDP had a strong positive effect, but the GDP and inflation did not.

Ben Khediri and Ben Khediri (2009) explored Islamic bank profitability in the MENA region further; they studied bank profitability by examining various variables from 1999-2006. The two proved that capitalization, management efficiency, economic growth, and inflation enhanced and improved bank profitability. On the other hand, if higher the monetary freedom of Islamic banks is negative the result of profitability and vice versa. The paper also indicated that the more diversified and better capitalized banks were relatively more profitable. Another researcher, Ghazali (2008), conducted research on 60 Islamic banks across 18 countries for a period of five years (from 2002 to 2007) and concluded that their capital strength and efficiency were related to their profitability. He stated that the impact of liquidity remained resolved and varied with the measure of profitability used. Moreover, Smaoui and Ben Salah (2012) studied 44 Islamic banks in the Gulf Cooperation Council (GCC) countries over the period of 1995-2009 and found that asset quality, a larger bank size, and inefficiency impacted bank profitability to a great extent.

Zeitun (2012) examined the determinants of profitability among Islamic and non-Islamic banks in the GCC. They concluded that bank equity was very important for the conventional banks but not for the Islamic banks. Moreover, they found efficiency, GDP, and inflation to be statistically significant. Hassan and Bashir (2003) compared Islamic and conventional national banks for the period of 1996 to 2008 using a regression model in which the ROE and ROA were employed alternately as dependent variables. The following independent variables were considered: GDP per capita, size, financial development indicator (FIR), liquidity, concentration, cost, and number of branches.

The review of literature clearly indicates that there is a gap in the research on the UAE banking sector. All the previous research on the Middle East compares Islamic banks and conventional banks, but hardly any work has been done to develop a set of variables that has the power to determine bank profitability. The present research is an attempt to fill the gap in the existing body of knowledge by setting into relief the most important determinants of the UAE banking sector. It adds value to the body of knowledge by putting together a comprehensive list of variables and the latest panel database and considering all the domestic banks in the UAE.

After examining the available literature, we posed the following research question: "What are the important possible indicators that impact the profitability of UAE banks?" Based on this research question, we formulated three hypotheses:

1. $H(1)$ : Macroeconomic indicators do not impact the banks' profitability.

H (0): Macroeconomic indicators impact the banks' profitability.

2. H (1): Industry-specific indicators do not impact the banks' profitability.

$H(0)$ : Industry-specific indicators impact the banks' profitability.

3. $\mathrm{H}(1)$ : Bank-specific indicators do not impact the banks' profitability.

H (0): Bank-specific indicators impact the banks' profitability. 


\section{Research Method}

The main objective of this study was to examine the variables or indicators that impacted the profitability of UAE banks. To achieve this objective, we employed the methodology described in this section. This section discusses the study variables and the statistical tools and techniques we applied while conducting the research. The study covered all the banks in the domestic banking sector of the UAE. The data were collected from secondary sources, particularly the bank's annual reports. Those banks that started operation and discontinued in the middle of the period under review were excluded. The sample contained 19 UAE domestic banks out of 23 existing banks. The list of the banks in the sample is given in below Table 1.

Table 1. List of banks in the study

\begin{tabular}{ll}
\hline 1 & National Bank of Abu Dhabi P.J.S.C \\
2 & Abu Dhabi Commercial Bank P.J.S.C \\
3 & Union National Bank \\
4 & Commercial Bank of Dubai P.J.S.C \\
5 & Emirates NBD Bank P.J.S.C \\
6 & Emirates Islamic Bank P.J.S.C. \\
7 & Mashreq Bank P.S.C \\
8 & Sharjah Islamic Bank P.J.S.C. \\
9 & Bank of Sharjah PSC \\
10 & United Arab Bank P.J.S.C \\
11 & The National Bank of R.A.K P.J.S.C \\
12 & National Bank of Fujairah PSC \\
13 & First Gulf Bank \\
14 & Abu Dhabi Islamic Bank P.J.S.C \\
15 & Arab Bank for Inv.\& Foreign Trade \\
16 & Dubai Islamic Bank P.J.S.C \\
17 & National Bank of U.A.Q PSC \\
18 & Commercial Bank International PLC \\
19 & Invest Bank PLC \\
\hline
\end{tabular}

We derived the bank-specific variables in this study from the financial statements of individual banks as well as the Bank Scope database. Moreover, we collected the macroeconomic variables, the annual inflation rates, and the annual GDP growth rates from the IMF and the UAE banking sector guide database then analyzed the data using SPSS and Gretl software.

We used panel data from an eight-year period (2006 to 2013). The panel data were advantageous as they allowed for the study of bank behavior over a period (Gujarati, 2003). Moreover, they had undergone regression analysis, with the fixed effects and random effects taken into consideration. The Hausman test is well known for distinguishing between fixed effects and random effects. It guides the choice between the two.

\subsection{Measures of Banks' Profitability}

\subsubsection{Dependent Variables}

The main objective of the paper was to determine the extent to which bank-specific, macroeconomic, and industry-specific measures influenced profitability. Based on a review of the literature, we identified various variables with which to measure the bank's profitability: return on assets (ROA), return on equity (ROE), and net interest margin (NIM). The NIM, ROA, and ROE are the three most commonly used financial performance indicators of banks. The ROA measures the overall performance of the bank. It has frequently been used in studies on bank determinants. The ROE is the return on the shareholder's investment. A business with a high return on equity is more likely to be capable of generating cash internally (Athanasoglou, Brissimis, \& Delis, 2008; Ho \& Saunders, 1981). 


\subsubsection{Independent Variables}

Under independent variables, this paper considers bank-specific variables, industry-specific variables, and macroeconomic variables.

The bank-specific variables include size, capital adequacy, liquidity, cost efficiency, income diversity, asset quality, risk-solvency ratios, and growth. The industry-specific variable is the market concentration. As for the macroeconomic variables, they include the GDP, the economic growth rate, and the average annual inflation rate.

\subsubsection{Bank-specific Variables}

Size: Empirical studies have considered size to be an important variable in the determination of profitability (Kosmidou et al., 2005; Dietrich \& Wanzenried, 2009). However, the literature presents mixed findings regarding the relationship between bank size and profitability. The size of the bank was considered to be positively associated with profitability. Larger banks achieved economies of scale, leading to more profitability (Staikouras \& Wood, 2004). Moreover, some researchers have argued that big banks are in a much better position to reap economies of scale and have greater diversification opportunities. According to Barros, Ferreira, and Williams (2007), large banks were generally able to raise less expensive capital, positively affecting their profitability (Smirlock, 1985). Relatively more long-intensive and smaller banks were more likely to perform better and less likely to perform poorly, whereas bigger and more diversified banks were less likely to perform well and more likely to perform poorly. The bigger banks increased the overall efficiency, positively affecting the profits of the banks (Ho \& Saunders, 1981).

However, Smirlock (1985) presented a contrary viewpoint: Islamic banks' sizes had significant negative effects on profitability. A greater ability to diversify assets may have partially offset any positive influence on profits due to economies of scale, resulting in a lower risk and a lower required return. Therefore, we hypothesized either a positive or negative relationship between bank sizes and profitability.

We measured the size of each bank using the logarithm of total assets. Concerning Islamic banks, the results regarding the effects of bank size on Islamic bank profitability in the literature appear to be mixed as well.

Capital Adequacy: This refers to the ability of the present capital to support the further growth of assets. Capital adequacy is the level of capital that banks require to withstand risks such as the credit, market, and operational risks to which they are exposed; to absorb potential losses; and to determine their expansion into risky but profitable ventures or areas. This has come to be known as the most important ratio for banks and a buffer against heavy losses that could threaten their very existence. Since banks are heavily leveraged institutions, they must maintain sufficient capital to cover their risk-weighted assets (RWAs). Banks with less capital adequacy are considered to be high risk, making it difficult to get cheaper sources of funds, increasing the cost of capital, and hampering their profitability. Higher bankruptcy costs leads to banks holding more equity to avoid periods of distress. Well-capitalized banks face lower expected bankruptcy costs, and this advantage "translates" into better profitability. Once more, capital adequacy was considered to be positively associated with profitability. Capital adequacy was significantly related to bank performance for all measures of profitability. Furthermore, profitability tended to be associated with banks that held relatively high amounts of capital and had negative-capital adequacy ratios as measured by Basel. We measured the capital adequacy ratios using the tier I ratio.

Liquidity: Earlier studies took liquidity as an indicator of banks' profitability. Again, based on past literature, the relationship between capital and profitability was mixed. The high liquidity of the banks negatively affected their profitability. High liquidity blocked the funds that could have been invested in the more profitable ventures. Negative liquidity, being negatively related to the performance of the Islamic banks, was mainly attributed to the conservative policies of these banks regarding fund allocation. In turn, high liquidity negatively affected the profit or performance level. The incentive to lend was lower in the case of UAE banks. Abu Loghod's (2015) analysis of Islamic bank results revealed that higher liquidity was associated with higher profits, and this supported the argument that well-capitalized banks generally faced lower financing costs, ultimately reducing their costs and enhancing their profitability. On the other hand, liquid assets generated lower returns, so a negative relationship with bank profitability was expected. Regarding liquidity risk, greater liquidity was associated with lower vulnerability to failure (Kosmidou et al., 2005). On the other hand, some surveys found liquidity to be positively linked to profitability. Generally, the banks that held reduced levels of liquid assets faced the risk of not being able to finance their daily operations (Guru, Staunton, \& Balashanmugam, 2002). The different studies used different measures of profitability.

Cost Efficiency: Also referred to as management quality (QM), cost efficiency plays a very important role in the overall profitability of banks. A cost-efficient bank would be able to generate more profitability. Hence, the banks 
with high expense-to-income ratios were considered to have low profitability. Kosmidou et al. (2005), Alexiou and Sofoklis (2009), and Dietrich et al. (2009) established that cost efficiency had a significant relationship with profit.

Asset Quality: Based on the earlier research, asset quality had a positive impact on overall company profitability. Asset quality was measured by the relationship of the impairment loss to the gross loans. The higher the ratio, the more problematic the loans were and vice versa. A higher ratio would be problematic for a bank, resulting in the deterioration of its profitability. It was also a measure of the credit risk of the bank. If the bank faced a serious asset quality problem and loan loss reserves were insufficient to allow the writing off of all bad loans, the excess would have to be written off against the shareholders' equity.

Income diversity: Income diversity measures the extent to which a bank's activities are diversified from traditional banking loan business. The non-interest income compared to the gross income is taken as a measure of the bank's income diversity. Research showed it to have a mixed relationship with bank profitability. Output diversifications permitted the banks to raise their revenue from non-traditional business, which, in turn, could have compensated for the lower interest margins that resulted from strong competition among traditional banking businesses. Valverde and Fernandez (2005) explained that the coexistence of paradoxical markets in the banking sector decreased the interest margins, possibly leading to an increase in the market power, especially in the European banking sector.

Risk-solvency ratios are referred to as gearing or leverage ratios. They measure the long-term solvency of banks. Higher leverage ratios indicate high bankruptcy and financial distress but enable firms to enhance their profitability by inserting the debt in their capital structures. Short-term solvency is the amount of a bank loan divided by the amount of its deposits at any given time. The higher the ratio, the more the bank relies on borrowed funds, which are generally costlier than most types of deposits.

Growth: The growth rates of banks can impact their overall profitability. Growing banks have ample opportunities, which may lead to better profitability than that which banks with low growth experience. The growth of the banks was measured in terms of the growth of their total loans.

\subsubsection{Industry-specific Variables}

Market Concentration: Market concentration is measured by a bank's share of total banking industry assets. Bank concentration equals the fraction of bank assets that the three largest commercial banks in the country hold. Returning to market concentration, it is evident that the concentration ratio had a negative and significant impact on the net interest margin alone.

\subsubsection{Macroeconomic Variables}

To reflect the impact of macroeconomic variables on the profitability of the banks, we used the GDP and the inflation rate as the explanatory variables.

Inflation: With an increase in inflation, a bank's interest rate rises, leading to increased overall profitability. Hence, higher inflation leads to increased profitably. However, the results were very ambiguous regarding inflation as a determinant. (Athanasoglou et al., 2005). By contrast, inflation was significantly negatively related to the performance of commercial banks. This was probably due to the fact that inflation could affect the value for money, people's purchasing power, and the real interest rates that banks charged and received. High inflation rates were generally associated with high loan interest rates, and, therefore, if inflation was not anticipated and banks were sluggish in the adjustment of their interest rates, it was possible for bank costs to increase faster than bank revenues and to adversely affect bank profitability.

Economic growth - A growing economy creates opportunities for high profitability. Hence, it is possible to measure economic growth using the GDP growth rate. A high GDP leads to better profitability by creating many opportunities. Table 2 below depicts the list of all variables used in this study with their abbreviations. 
Table 2. List of variables

\begin{tabular}{|c|c|c|}
\hline Performance area & Formula used & Symbol \\
\hline \multicolumn{3}{|l|}{ Dependent variable } \\
\hline Net Interest Margin & $\begin{array}{l}\text { Difference between the Interest Received to Interest Paid } \\
\text { divided by the Average Invested Assets }\end{array}$ & NIM \\
\hline Return On Avg Assets & Measure of overall profitability & ROA \\
\hline Return On Avg Equity & Measure of overall profitability & $\mathrm{ROE}$ \\
\hline \multicolumn{3}{|l|}{ Independent variables } \\
\hline Asset Quality & Impaired Loans to Gross Loans & ILTGL \\
\hline \multicolumn{3}{|l|}{ Bank specific variables } \\
\hline Capital Adequacy & Tier 1 Regulatory Capital Ratio & CAR \\
\hline Cost Efficiency & Measured by the ratio of Cost To Income Ratio & CTI \\
\hline Economy growth & Rate of growth of real GDP & GDP \\
\hline Financial Leverage & Cap Funds to total Liabilities & CFTL \\
\hline Growth & Rate of growth of Gross Loans & GTL \\
\hline Income from non traditional sources & Non Int Revenues to Gross Revenues & NIRGR \\
\hline Income from traditional sources & Net Int Rev to Avg Assets & IRGR \\
\hline Industry concentration & Banks assets to total banking assets & $\mathrm{CON}$ \\
\hline \multicolumn{3}{|l|}{ Industry specific variables } \\
\hline Inflation & Rate of inflation & INF \\
\hline Liquidity & Liquid Assets to Dep \& ST Funding & LATDF \\
\hline \multicolumn{3}{|l|}{ Macroeconomic variables } \\
\hline Short term solvency & loans to customers Deposits & STS \\
\hline Size & $\log$ of Total Assets & LOA \\
\hline
\end{tabular}

\section{Analysis and Discussion}

The primary purpose of the study was to examine the variables that impacted the profitability of UAE banks. Table 3 gives the detailed descriptive status of the variables. The descriptions clearly indicate that the average ROA of UAE banks was $2 \%$, whereas the ROE had an average value of $13 \%$. The average bank in the UAE banking sector had an impressive $16 \%$ tier I ratio. The data suggested that there was little variation in profitability where the growth of loans showed a very high standard deviation. All the variables were tested for multicollinearity. Table 4 includes the results of the correlation of selected dependent and independent variables. The results of correlation among most of the variables were positive except for those associated with a few variables (for instance, the capital adequacy, size, and ROA).

To determine the firm-specific and country-specific variables of the UAE banking sector, a panel data analysis was performed with attention to the fixed effects and random effects. One common method for testing which model was more appropriate was the Hausman test. We employed the test that Hausman (1978) and Hausman and Taylor (1981) applied to compare the fixed and random effect estimates of coefficients. The intention was to find out whether there was a significant correlation between the unobserved individual-specific random effects and the regressors. Table 5 depicts the results of the Hausman test with the net interest model (NIM). Based on the analysis, the results indicated that the tier I capital ratio was positively related to the NIM. The banks with the highest tier capital adequacy experienced more profitability. The income diversity, measured according to the ratio of non-income revenues to gross revenue, had a negative relationship with the NIM. Impairment loss was another significant factor and was negatively related to the NIM. A higher impairment loss led to decreased profitability. The cost to income ratio, which indicated the operational efficiency of the banks, had a significant negative relationship with the NIM. The higher the ratio, the 
lower the operating efficiency. The banks with higher operating efficiencies would be able to generate better results. All other variables, including the macroeconomic and industry-level indicators had no impact on the NIM.

Table 3. Summary Statistics

\begin{tabular}{|c|c|c|c|c|}
\hline Variable & Mean & Median & Minimum & Maximum \\
\hline CAR & 18.2366 & 17.6300 & 6.74000 & 35.3900 \\
\hline CFTA & 17.2326 & 17.2326 & 9.79300 & 28.5150 \\
\hline CFTL & 15.6217 & 14.4100 & -58.6700 & 60.9100 \\
\hline $\mathrm{CON}$ & 0.0912568 & 0.0660855 & 0.00558957 & 0.296202 \\
\hline CTI & 34.8654 & 33.0410 & 12.2930 & 96.3960 \\
\hline GDP & 3.65150 & 4.48250 & -4.80400 & 8.20000 \\
\hline GTL & 20.8518 & 13.9900 & -15.0300 & 199.450 \\
\hline ILTGL & 6.02272 & 4.32000 & 0.650000 & 26.5800 \\
\hline INF & 4.77225 & 1.64500 & 0.520000 & 12.3000 \\
\hline LATDF & 27.9764 & 25.6330 & 0.855000 & 80.9830 \\
\hline LOA & 4.38095 & 4.37597 & 3.00356 & 5.53410 \\
\hline LTCD & 118.500 & 101.775 & 32.9600 & 820.320 \\
\hline NIM & 3.73646 & 3.46200 & 1.38200 & 10.2420 \\
\hline ROA & 2.24305 & 2.06750 & -2.63500 & 6.72700 \\
\hline ROE & 13.7408 & 13.9280 & -16.5990 & 34.7950 \\
\hline Variable & Std. Dev. & C.V. & Skewness & Ex. kurtosis \\
\hline CAR & 5.99057 & 0.328492 & 1.11703 & 0.923841 \\
\hline CFTA & 3.43627 & 0.199405 & 0.653286 & 1.31755 \\
\hline CFTL & 9.81499 & 0.628293 & -1.65874 & 23.8195 \\
\hline $\mathrm{CON}$ & 0.0771683 & 0.845617 & 0.760351 & -0.474172 \\
\hline CTI & 11.0708 & 0.317530 & 1.32935 & 5.12263 \\
\hline GDP & 3.64865 & 0.999220 & -1.29831 & 0.997859 \\
\hline GTL & 28.2703 & 1.35578 & 2.78641 & 12.2839 \\
\hline ILTGL & 5.19582 & 0.862704 & 1.50736 & 2.24618 \\
\hline INF & 4.81090 & 1.00810 & 0.571509 & -1.55280 \\
\hline LATDF & 13.7878 & 0.492838 & 0.829315 & 1.03265 \\
\hline LOA & 0.649214 & 0.148190 & -0.0900221 & -1.00464 \\
\hline LTCD & 90.3047 & 0.762066 & 5.82850 & 36.2149 \\
\hline NIM & 1.45405 & 0.389153 & 2.44778 & 8.01832 \\
\hline ROA & 1.35676 & 0.604872 & 0.113786 & 1.23938 \\
\hline ROE & 7.54652 & 0.549204 & -0.398786 & 1.75931 \\
\hline
\end{tabular}

Table 4. Correlations

\begin{tabular}{|c|c|c|c|c|c|c|c|c|c|c|c|c|c|}
\hline & LOA & CAR & GTL & LTCD & $\mathrm{CTI}$ & LADSF & $\mathrm{INF}$ & GDPgr & NIRGR & INGL & ILTGL & CFTA & \\
\hline LOA & 1 & & & & & & & & & & & & \\
\hline CAR & $-.392^{* *}$ & 1 & & & & & & & & & & & \\
\hline GTL & -.022 & $-.176^{*}$ & 1 & & & & & & & & & & \\
\hline LTCD & $-.293^{* *}$ & .079 & -.050 & 1 & & & & & & & & & \\
\hline CTI & -.056 & -.110 & -.056 & $-.223^{* *}$ & 1 & & & & & & & & \\
\hline LADSF & $-.224^{* *}$ & $.468^{* * *}$ & -.076 & .105 & $-.161^{*}$ & 1 & & & & & & & \\
\hline INF & -.140 & $-.187^{*}$ & $.586^{* *}$ & .088 & -.048 & .103 & 1 & & & & & & \\
\hline GDPgr & -.082 & .033 & $.408^{* *}$ & .076 & .040 & .140 & $.526^{* *}$ & 1 & & & & & \\
\hline NIRGR & .020 & -.100 & $.247^{* *}$ & .015 & -.110 & $.304^{* *}$ & $.330^{* *}$ & $.208^{*}$ & 1 & & & & \\
\hline INGL & $-.328^{* *}$ & $.286^{* *}$ & .110 & .042 & .091 & .097 & $.288^{* * *}$ & .131 & .008 & 1 & & & \\
\hline ILTGL & $-.286^{* *}$ & -.016 & $-.296^{* *}$ & .109 & $.281^{* *}$ & .060 & $-.388^{* *}$ & -.059 & .012 & $-.258^{* *}$ & 1 & & \\
\hline CFTA & $-.326^{* *}$ & $.579^{* *}$ & -.108 & -.010 & -.041 & .155 & $-.229^{* *}$ & $-.181^{*}$ & -.100 & $.219^{* *}$ & .005 & 1 & \\
\hline $\mathrm{CON}$ & $.245^{* *}$ & $-.344^{* *}$ & -.056 & .093 & .088 & $-.214^{* *}$ & -.011 & -.005 & .038 & $-.372^{* *}$ & $.218^{* *}$ & $-.474^{* *}$ & 1 \\
\hline
\end{tabular}


Table 5. Results of Panel Regression Analysis for Net Interest Margin (NIM)

Model 1: Fixed-effects, using 152 observations

Included 19 cross-sectional units

Time-series length $=8$

Dependent variable: NIM

\begin{tabular}{|c|c|c|c|c|c|}
\hline & Coefficient & Std. Error & t-ratio & $p$-value & \\
\hline CAR & 0.0394672 & 0.0179484 & 2.1989 & 0.02980 & $* *$ \\
\hline CFTA & 0.000654525 & 0.0202248 & 0.0324 & 0.97424 & \\
\hline $\mathrm{CON}$ & -0.981918 & 2.93293 & -0.3348 & 0.73837 & \\
\hline Const & 4.16842 & 2.10052 & 1.9845 & 0.04949 & $* *$ \\
\hline CTI & -0.0274242 & 0.0081085 & -3.3822 & 0.00097 & $* * *$ \\
\hline GDP & -0.00452871 & 0.0154953 & -0.2923 & 0.77059 & \\
\hline GTL & 0.00248701 & 0.00209003 & 1.1899 & 0.23642 & \\
\hline ILTGL & 0.0133657 & 0.0157362 & 0.8494 & 0.39737 & \\
\hline INF & -0.0166877 & 0.0174732 & -0.9550 & 0.34148 & \\
\hline IRGR & 0.0989065 & 0.0410244 & 2.4109 & 0.01743 & $* *$ \\
\hline LATDF & -0.0305387 & 0.00588649 & -5.1879 & $<0.00001$ & $* * *$ \\
\hline LOA & 0.163904 & 0.424567 & 0.3860 & 0.70014 & \\
\hline LTCD & -0.000523775 & 0.000637044 & -0.8222 & 0.41260 & \\
\hline NIRGR & -0.020779 & 0.00594106 & -3.4975 & 0.00066 & $* * *$ \\
\hline Mean dependent var & \multicolumn{2}{|c|}{3.736457} & dependent var & \multicolumn{2}{|c|}{1.454052} \\
\hline Sum squared resid & \multicolumn{2}{|c|}{29.94235} & of regression & \multicolumn{2}{|c|}{0.499519} \\
\hline R-squared & \multicolumn{2}{|c|}{0.906212} & sted R-squared & \multicolumn{2}{|c|}{0.881983} \\
\hline $\mathrm{F}(31,120)$ & \multicolumn{2}{|c|}{37.40245} & $\mathrm{ue}(\mathrm{F})$ & \multicolumn{2}{|c|}{$5.38 \mathrm{e}-48$} \\
\hline Log-likelihood & \multicolumn{2}{|c|}{-92.20855} & ke criterion & \multicolumn{2}{|c|}{248.4171} \\
\hline Schwarz criterion & \multicolumn{2}{|c|}{345.1813} & lan-Quinn & \multicolumn{2}{|c|}{287.7261} \\
\hline Rho & \multicolumn{2}{|c|}{0.453988} & in-Watson & \multicolumn{2}{|c|}{0.939866} \\
\hline
\end{tabular}

Test for differing group intercepts -

Null hypothesis: The groups have a common intercept

Test statistic: $\mathrm{F}(18,120)=17.3328$

With p-value $=\mathrm{P}(\mathrm{F}(18,120)>17.3328)=2.41449 \mathrm{e}-025$

Breusch-Pagan test

Null hypothesis: Variance of the unit-specific error $=0$

Asymptotic test statistic: Chi-square $(1)=73.3541$

with $\mathrm{p}$-value $=1.08356 \mathrm{e}-017$

Hausman test

Null hypothesis: GLS estimates are consistent

Asymptotic test statistic: Chi-square (13) $=56.2682$

with $\mathrm{p}$-value $=2.41736 \mathrm{e}-007(.000)$ 
Table 6. Results of Panel Regression analysis as ROA as dependent variable

Model 2: Fixed-effects, using 152 observations

Included 19 cross-sectional units

Time-series length $=8$

Dependent variable: ROA

\begin{tabular}{|c|c|c|c|c|c|}
\hline & Coefficient & Std. Error & t-ratio & $\mathrm{p}$-value & \\
\hline$\overline{\text { CAR }}$ & 0.041384 & 0.0247928 & 1.6692 & 0.09769 & $*$ \\
\hline CFTA & 0.00500064 & 0.0279372 & 0.1790 & 0.85824 & \\
\hline $\mathrm{CON}$ & 1.66566 & 4.05137 & 0.4111 & 0.68171 & \\
\hline Const & 2.8467 & 2.90153 & 0.9811 & 0.32852 & \\
\hline CTI & -0.0589109 & 0.0112006 & -5.2596 & $<0.00001$ & $* * *$ \\
\hline GDP & 0.0390691 & 0.0214042 & 1.8253 & 0.07044 & $*$ \\
\hline GTL & 0.000848611 & 0.00288703 & 0.2939 & 0.76931 & \\
\hline ILTGL & -0.0333053 & 0.021737 & -1.5322 & 0.12811 & \\
\hline INF & 0.0232154 & 0.0241364 & 0.9618 & 0.33806 & \\
\hline IRGR & 0.0550019 & 0.0566686 & 0.9706 & 0.33371 & \\
\hline LATDF & -0.00290945 & 0.00813123 & -0.3578 & 0.72111 & \\
\hline LOA & -0.196997 & 0.58647 & -0.3359 & 0.73753 & \\
\hline LTCD & -0.000168874 & 0.000879971 & -0.1919 & 0.84814 & \\
\hline NIRGR & 0.0306887 & 0.0082066 & 3.7395 & 0.00028 & $* * *$ \\
\hline
\end{tabular}

Mean dependent var

2.243053

S.D. dependent var

1.356761

Sum squared resid

57.13270

S.E. of regression

0.690004

R-squared

0.794458

Adjusted R-squared

0.741359

$\mathrm{F}(31,120)$

14.96198

P-value(F)

$2.31 \mathrm{e}-28$

Log-likelihood

$-141.3124$

Akaike criterion

346.6247

Schwarz criterion

443.3889

Hannan-Quinn

385.9337

Rho

0.057160

Durbin-Watson

1.710031

Test for differing group intercepts -

Null hypothesis: The groups have a common intercept

Test statistic: $\mathrm{F}(18,120)=5.26291$

With $\mathrm{p}$-value $=\mathrm{P}(\mathrm{F}(18,120)>5.26291)=8.69453 \mathrm{e}-009$

\section{Breusch-Pagan test}

Null hypothesis: Variance of the unit-specific error $=0$

Asymptotic test statistic: Chi-square $(1)=9.70185$

With $p$-value $=0.00184083$

\section{Hausman test}

Null hypothesis: GLS estimates are consistent

Asymptotic test statistic: Chi-square (13) $=60.549$

With $\mathrm{p}$-value $=4.18968 \mathrm{e}-008$ 
Table 6 includes the panel data regression results with the ROA as the dependent variable. The ROA was positively related to the capital adequacy. A higher tier I capital ratio led to a high ROA. Diversification was positively related to the ROA, with the ratio of non-interest income to gross revenues being positively related to the ROA. Once more, the cost efficiency had a positive relationship to the ROA. The higher the cost to income ratio, lower the cost efficiency would be, bringing down the ROA of the banks. The economic indicators had no influence on the NIM, but the coefficient of the GDP showed that the highest GDP growth had the capacity to lead to higher ROAs for banks.

The third model includes the results, with the ROE as the dependent variable (see table 7). The coefficient of non-interest income to gross revenues was positive and highly significant, suggesting that the non-conventional revenue generated would enhance the ROE. Also, a higher capital adequacy ratio would lead to higher profitability by increasing creditworthiness and reducing the funding cost. The loan loss provision and cost to income ratio had significant negative impacts on all measures of profitability. This also indicated that the banks could increase their performance by providing more unconventional services and enhancing their cost efficiency. To sum up, the results of the analysis indicated that increasing overall profitability, cost efficiency, asset quality, and capital adequacy would be the most important actions on bank-specific variables. The banks with higher incomes from non-interest-based sources had better overall profitability as their ROAs and ROEs indicated. However, the higher non-interest-income-to-total-revenue ratios would have a negative impact on the NIM. A growing economy would see an increase in the ROA and the ROE.

Table 7. Results of Panel Regression with ROE as the dependent variable

Model 3: Fixed-effects, using 152 observations

Included 19 cross-sectional units

Time-series length $=8$

Dependent variable: ROE

\begin{tabular}{|c|c|c|c|c|c|}
\hline & Coefficient & Std. Error & t-ratio & $\mathrm{p}$-value & \\
\hline$\overline{\mathrm{CAR}}$ & -0.107756 & 0.142845 & -0.7544 & 0.45211 & \\
\hline CFTA & 0.0891658 & 0.160962 & 0.5540 & 0.58064 & \\
\hline $\mathrm{CON}$ & 4.82077 & 23.3423 & 0.2065 & 0.83673 & \\
\hline Const & -0.859235 & 16.7174 & -0.0514 & 0.95909 & \\
\hline CTI & -0.344962 & 0.0645329 & -5.3455 & $<0.00001$ & $* * *$ \\
\hline GDP & 0.344121 & 0.123322 & 2.7904 & 0.00613 & $* * *$ \\
\hline GTL & 0.00327154 & 0.0166338 & 0.1967 & 0.84441 & \\
\hline ILTGL & -0.434674 & 0.125239 & -3.4707 & 0.00072 & $* * *$ \\
\hline INF & 0.120729 & 0.139064 & 0.8682 & 0.38704 & \\
\hline IRGR & 0.578281 & 0.3265 & 1.7712 & 0.07907 & $*$ \\
\hline LATDF & -0.0226121 & 0.0468487 & -0.4827 & 0.63022 & \\
\hline LOA & 4.09173 & 3.37899 & 1.2109 & 0.22830 & \\
\hline LTCD & -0.00403134 & 0.00507002 & -0.7951 & 0.42811 & \\
\hline NIRGR & 0.205131 & 0.047283 & 4.3384 & 0.00003 & $* * *$ \\
\hline Mean dependent var & \multicolumn{2}{|c|}{13.74083} & dependent var & \multicolumn{2}{|c|}{7.546522} \\
\hline Sum squared resid & \multicolumn{2}{|c|}{1896.563} & of regression & \multicolumn{2}{|c|}{3.975511} \\
\hline R-squared & \multicolumn{2}{|c|}{0.779455} & usted R-squared & \multicolumn{2}{|c|}{0.722481} \\
\hline $\mathrm{F}(31,120)$ & \multicolumn{2}{|c|}{13.68088} & lue(F) & \multicolumn{2}{|c|}{$1.21 \mathrm{e}-26$} \\
\hline Log-likelihood & \multicolumn{2}{|c|}{-407.4964} & ike criterion & \multicolumn{2}{|c|}{878.9929} \\
\hline Schwarz criterion & \multicolumn{2}{|c|}{975.7570} & nan-Quinn & \multicolumn{2}{|c|}{918.3018} \\
\hline Rho & \multicolumn{2}{|c|}{0.182003} & bin-Watson & \multicolumn{2}{|c|}{1.516399} \\
\hline
\end{tabular}

Test for differing group intercepts -

Null hypothesis: The groups have a common intercept

Test statistic: $\mathrm{F}(18,120)=5.33314$

With $\mathrm{p}$-value $=\mathrm{P}(\mathrm{F}(18,120)>5.33314)=6.46982 \mathrm{e}-009$ 


\section{Breusch-Pagan test}

Null hypothesis: Variance of the unit-specific error $=0$

Asymptotic test statistic: Chi-square (1) $=13.9329$

With p-value $=0.00018945$

\section{Hausman test}

Null hypothesis: GLS estimates are consistent

Asymptotic test statistic: Chi-square(13) $=50.9341$

with $\mathrm{p}$-value $=2.05972 \mathrm{e}-006$

\section{Conclusion}

To ensure a healthy banking sector, it is very important to gauge the profitability of the banks. This study was an attempt to identify the impact of various variables on banks' profitability in the domestic commercial banking sector of the UAE, focusing on a sample of 19 banks over eight years (2006-2013) and using balanced panel data. The empirical results of the research clearly indicated that the cost efficiency, maintaining a high capital adequacy ratio, and improving asset quality were the most significant variables that could impact the profitability of banks for all measures of profits. The banks could also have enhanced their profitability by diversifying into nontraditional source revenue, but that would have had a negative impact on the NIM. To conclude, this study put into relief the profitability-enhancing model, which the banks could use to increase their performance.

\section{Limitations and Future Research Avenues}

Although this study focused on the UAE - one of the important emerging markets - it did not offer an in-depth understanding of matters beyond the determinants of banks' profitability in the UAE from 2006 till 2013. The period of the study included the 2008 global financial crisis, but it was not possible to take those changes into consideration due to the non-availability of data. This may have had a small impact on the results too. These two limitations of the study can be seen as determining the scope of future research. The researchers could study and compare the results before and after the bank crisis by taking all variables into consideration.

\section{References}

Abu Loghod, H. (2015). Do Islamic Banks Perform Better than Conventional Banks? Evidence from Gulf $\begin{array}{lll}\text { Cooperation Council countries, } & \text { Econpapers.repec.org, } \\ \text { http://EconPapers.repec.org/RePEc:api:apiwps:1011 (accessed 3 February 2015). }\end{array}$

Alexiou, C. \& Sofoklis, V. (2009). Determinants of bank profitability: Evidence from the Greek banking sector. Ekon. an., 54(182), 93-118. https://doi.org/10.2298/eka0982093a

Athanasoglou, P., Brissimis, S. \& Delis, M. (2008). Bank-specific, industry-specific and macroeconomic determinants of bank profitability, Journal of International Financial Markets, Institutions and Money, 18(2), pp. 121-136. https://doi.org/10.1016/j.intfin.2006.07.001

Bashir, A.H.M. (1999). Risk and Profitability Measures in Islamic Banks: The Case of Two Sudanese Banks. Islamic Economic Studies, 6(2), 1-24.

Ben Khediri, K., \& Ben-Khediri, H. (2009). Determinants of Islamic Bank Profitability in the MENA Region. International Journal of Monetary Economics and Finance, 2(3-4), 409 - 426. https://doi.org/10.1504/IJMEF.2009.029072

Barros Carlos, C. Ferreira, J. Williams. (2007). Analyzing the determinants of performance of best and worst European banks: A mixed logit approach. Journal of Banking \& Finance, 31, 2189-2203. https://doi.org/10.1016/j.jbankfin.2006.11.010

Dietrich, A. \& Wanzenried, G. (2009). Determinants of Bank Profitability Before and During the Crisis: Evidence from Switzerland. SSRN Journal. https://doi.org/10.2139/ssrn.1370245

Ghazali M. B. (2008). The Bank-Specific and Macroeconomic Determinants of Islamic Bank Profitability: Some International Evidence.

Retrieved

from http://dspace.fsktm.um.edu.my/bitstream/1812/752/3/FULL\%20REPORT.pdf

Golin, J. \& Delhaise, P. (2013). The Bank Credit Analysis Handbook, Wiley, Hoboken.

Gujarati, D. (2003). Basic econometrics, McGraw-Hill, New York. 
Guru, B. K. \& Staunton, J. Balashanmugam, B. (2002). Determinants of commercial Bank Profitability in Malaysia, Working Paper, Multimedia University.

Hassan, M.K. \& Bashir, A.M. (2003). Determinants of Islam banking industry, paper presented at the Economic Research Forum 10th Conference, available at: www.nzibo.com/ IB2/Determinants.pdf

Hausman, J. A. (1978). Specification tests in econometrics. Econometrica, 46(6), 1251- 1272. https://doi.org/10.2307/1913827

Hausman, J. A. \& Taylor, W. E. (1981). A Generalized Specification Test. Economics Letters, 8(3), 239-245. https://doi.org/10.1016/0165-1765(81)90073-2

Ho, T. \& Saunders, A. (1981). The determinants of bank interest margins: theory and empirical evidence. Journal of Financial and Quantitative Analyses, 16, 581-600. https://doi.org/10.2307/2330377

Kosmidou, K., Tanna, S. \& Pasiouras, F. (2005). Determinants of Profitability of Domestic UK Commercial Banks: Panel Evidence from the Period 1995-2002. Money Macro and Finance Research Group Conference.

Olweny, T. \& Shipho, T. M. (2011). Effects of Banking Sectoral Variables on the Profitability of Commercial Banks in Kenya. Economics and Finance Review, 1(5), 01-30.

Smaoui H., \& Ben Salah, I.(2012). Profitability of Islamic Banks In The GCC Region. Global Economy and Finance Journal, 5(1), 85 - 102.

Smirlock, M. (1985). Evidence on the (Non) Relationship between Concentration and Profitability in Banking. Journal of Money, Credit and Banking, 17(1), 69. https://doi.org/10.2307/1992507

Staikouras, C., \& Wood, G. (2004). The determinants of European bank profitability, International Business and Economics Research Journal, 3(6), 57-68.

Valverde, S.C. \& Fernandez, F.R. (2005). The determinants of bank margins revisited: a note on the effect of diversification, Working Paper No. 05/11.

Zeitun, R. (2012). Determinants of Islamic and Conventional Banks Performance In GCC Countries Using Panel Data Analysis. Global Economy and Finance Journal, 5(1), 53 - 72. 